\title{
OUTCOME OF CEREBRAL CONTUSIONS DUE TO TRAUMATIC BRAIN INJURY
}

Zubair Ahmed khan ${ }^{\mathrm{a}}$, Habib Sultan ${ }^{\mathrm{a}}$, Amir Aziza, Shahrukh Rizvi ${ }^{\mathrm{a}}$, Tauqeer Ahmed ${ }^{\mathrm{a}}$, Waseem Ahmad ${ }^{\mathrm{a}}$

aDepartment of Neurosurgery, Postgraduate Medical Institute, Lahore General Hospital, Lahore.

\begin{abstract}
:
BACKGROUND \& OBJECTIVE: To compare the results of surgically operated vs conservatively treated patients of cerebral contusions due to traumatic brain injury.

METHODOLOGY: This comparative study was conducted from January 2012 to December 2014 at the department of Neurosurgery, PGMI Lahore General Hospital, Lahore. A total of 50 patients were included in this study of both gender (male and female) and in the age range of 15-65 years. In our study 20 patients were managed conservatively while other 30 patients were operated for cerebral contusions. The mode of injury in our study was road traffic accidents and history of falls.

RESULTS: Out of 50 patients, there were $41(82 \%)$ males and $09(18 \%)$ female patients. Their age ranged from 15 - 65 years. In this study the overall mean age is 38.36 years. The maximum numbers of patients were in their third and fourth decades of life. In our study the duration of hospital stay in conservatively managed patients was longer as compared to surgically treated patients who were discharged earlier. Mortality rate in surgically managed patients having a GCS ranged between 09 to 12 was very low contrary to the conservatively managed group, similarly the rate of delayed contusion formation and edema was also low in surgically managed patients as compared to those who were managed conservatively.

CONCLUSION: Surgically managed patients of cerebral contusions in traumatic brain injury has better outcome and decreased hospital stay as compared to conservatively managed patients.

KEYWORDS: Cerebral contusion, Traumatic brain injury, Glasgow Coma Scale (GCS).
\end{abstract}

doi: https://doi.org/10.37723/jumdc.v11i1.263

How to cite this:

Sultan H, Amir A, Khan ZA, Rizvi S, Ahmed T, Ahmed W. OUTCOME OF CEREBRAL CONTUSIONS DUE TO TRAUMATIC BRAIN INJURY. jumdc. 2020;11(1):39-43

doi: https://doi.org/10.37723/jumdc.v11i1.263

This is an Open Access article distributed under the terms of the Creative Commons Attribution License (http://creativecommons.org/licenses/by/4.0), which permits unrestricted use, distribution, and reproduction in any medium, provided the original work is properly cited.

\section{INTRODUCTION:}

Traumatic brain injury (TBI), also known as intracranial injury, is defined as damage to the brain resulting from external mechanical force, such as rapid acceleration or deceleration, impact, blast waves, or penetration by a projectile ${ }^{[1]}$.

Traumatic brain injury (TBI) is the most disabling of traumatic injuries often leading to lifelong physical, psychological, behavioral, cognitive and emotional impairments ${ }^{[2,3]}$. Nearly half of hospitalized survivors of TBI experience

Corresponding Author:

Dr. Habib Sultan,

I Department of Neurosurgery, Postgraduate

Medical Institute Lahore General Hospital, Lahore. I Email: drhabibneuro@gmail.com 
long term disabilities and constituting one of the largest expenditures in the Health Care System ${ }^{[4,5]}$. TBI encompass numerous types of insults to the brain, with one of the most severe being a hemorrhagic cerebral contusion. TBI associated with cerebral contusion is a frequent cause of death \& disability in trauma patients ${ }^{[6]}$. Cerebral contusion is derived from a Latin word contusion cerebri meaning a bruise of the brain tissue $^{[7]}$. Cerebral contusion, also known as brain Contusion occurs due to a bruise or injury to a region of the brain tissue. Contusions occur primarily in the cortical tissue, especially under the site of impact or in areas of brain located near sharp ridges on the inside of skull .It is commonly occur in coup or counter-coup injuries. In coup injuries, the brain is injured directly under the area of impact, while in counter-coup injuries it is injured on the opposite side of impact. Sign \& symptoms of cerebral contusions depend upon the location, size and severity of the injury.

CT scanning is an excellent modality for defining cerebral contusions and is the most preferred acute imaging modality, because it can be performed quickly and also in the presence of life support equipment's ${ }^{[8,9,10]}$. Contusions often are not appreciated on the first CT scan obtained immediately after trauma, but they become obvious on follow-up scans.

The outcome of TBI depends on the cause and location of the injury. The outcome, severity and extent of neurological damage can range from a good recovery to death of the patient.

\section{METHODOLOGY:}

This study was conducted at the department of Neurosurgery Postgraduate Medical Institute Lahore General Hospital, Lahore from Jan 2012 to Dec 2014, with a total duration of two years. The study has been approved by the Ethical review committee of Postgraduate Medical Institute, Lahore General Hospital, Lahore. The patient's age ranges b/w 15-65 years and both sex were included in this study. A total 50 patients of cerebral contusions due to traumatic brain injury following road traffic accidents or history of falls confirmed on CT scan were included in our study. In our study 20 patients were managed conservatively while other 30 patients were operated for cerebral contusions. All patients with Contusions in Frontal, Parietal and Temporal regions having Volume of blood $20 \mathrm{ml}$ or more with GCS between $(04-12)$ were included in the study. Those with associated extradural haematoma (EDH), \& intraventicular bleed, associated Skull fractures with age above 65 years and below 15 years were excluded from the study.

\section{RESULTS:}

Total patients included in the study were 50 . Among them, males were 41 (82\%) and females were $09(18 \%)$ with M: F ratio of $4: 1$. The youngest patient was of 15 years and the oldest was 64 years of age. The mean age was 38 years and the maximum numbers of patients were in third and fourth decades of life. Patients with GCS of (3-5), (6-8) and (9-12) were managed both conservatively and surgically (Table-I).

Involvement of different lobes of cerebrum and their management is shown in table-II, temporal lobe being most commonly involved.

Surgery performed within first 24 hours has good results as compared to delayed surgery with much less hospital stay and mortality rate than those managed conservatively. Rate of contusion expansion and edema is also high in conservatively managed patients (Table-III).

Table-I: Pre-operative status \& distribution of hospital study.

\begin{tabular}{|c|c|c|}
\hline GCS & $\begin{array}{c}\text { Conserv } \\
\text { ative }\end{array}$ & Surgery \\
\hline $\mathbf{3 - 5}$ & $06(30 \%)$ & $04(13 \%)$ \\
\hline $\mathbf{6 - 8}$ & 0 & $14(47 \%)$ \\
\hline $\mathbf{9 - 1 2}$ & $14(70 \%)$ & $12(40 \%)$ \\
\hline Total & $\begin{array}{c}20 \\
\text { Patients }\end{array}$ & 30 Patients \\
\hline $\begin{array}{c}\text { Duration } \\
\text { of hospital } \\
\text { study }\end{array}$ & $\begin{array}{c}\text { Average } \\
22 \text { days }\end{array}$ & $\begin{array}{c}\text { Average } 16 \\
\text { days }\end{array}$ \\
\hline
\end{tabular}




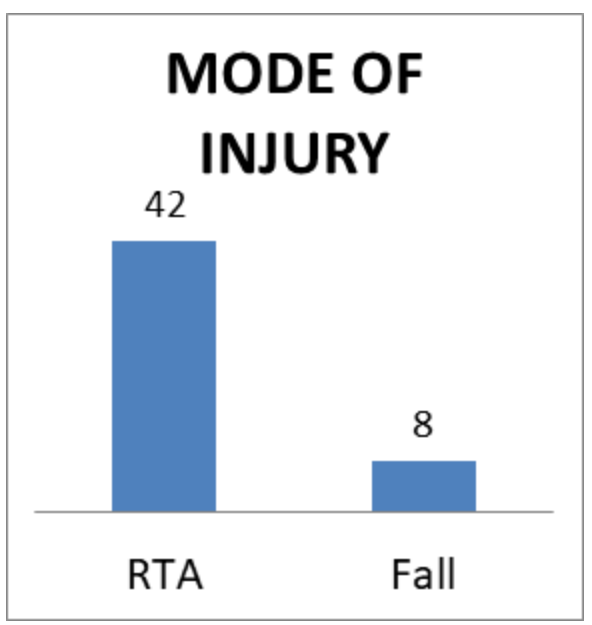

Figure-I: Mode of Injury.

Table-II: Cerebral lobe Involvement.

\begin{tabular}{|c|c|}
\hline Conservative & Surgery \\
\hline $\begin{array}{c}\text { Temporal }-6 \\
\text { patients (30\%) }\end{array}$ & $\begin{array}{c}\text { Temporal }-14 \\
\text { patients (47\%) }\end{array}$ \\
\hline Frontal-10 \\
patients (50\%) & $\begin{array}{c}\text { Frontal-12 patients } \\
(50 \%)\end{array}$ \\
\hline Parietal--04 & $\begin{array}{c}\text { Parietal--04 } \\
\text { patients (13\%) }\end{array}$ \\
patients (20\%) & Total--30 patients \\
\hline Total --20 patients & \\
\hline
\end{tabular}

Table-III: Outcome.

\begin{tabular}{|c|c|}
\hline Conservative & Surgery \\
\hline GCS 3-5 & GCS 3-5 \\
All 6 Patients died & All 4 Patients died \\
Mortality 100\% & Mortality 100\% \\
\hline & GCS 6-8 \\
& 06 Died \\
& 04 Same status \\
& 04 Improved \\
& Mortality 43\% \\
\hline GCS 9-12 & GCS 9-12 \\
9 Died & 2 died \\
3 Same status & 1 same status \\
2 Improved & 1 worsen \\
Mortality 64\% & 8 improved \\
Survival 36\% & Mortality 17\% \\
& Survival 83\% \\
\hline
\end{tabular}

JUMDC Vol. 11, Issue 1, January-March 2020

\section{DISCUSSION:}

Traumatic brain injury is the leading cause of mortality and morbidity in developing as well as in most of the developed countries ${ }^{[11]}$. Road traffic accidents are a major cause of cerebral contusions worldwide but especially in developing and emerging countries ${ }^{[12]}$. Cerebral parenchymal injury is evident in a considerable number of head injury victims. The most significant structural abnormality of the brain is contusion occurring in the brain parenchyma, which is a multifarious and dynamic area, due to primary lesion and is related to ischemic and inflammatory process that requires a comprehensive knowledge and proper management plan. Cerebral contusions account for $25-30 \%$ of severe head injuries and $8.5 \%$ of all traumatic brain injuries.

In our study we present a review of important aspects of cerebral contusion, comparison of conservatively managed and surgically treated patients of cerebral contusions in head injury patients over a wide range of Glasgow Coma Scale between 4 to 12 . In our study of 50 patients, 41 were males and only 9 were females in whom 20 patients were managed conservatively while remaining 30 patients were operated from January 2012 to December 2014. The modes of injuries in our study were road traffic accidents and history of fall.

In our study we managed patients with cerebral contusions in different lobes of the brain as shown in (table-II). Kawamata, et al conducted a study in Japan on 182 patients with cerebral contusions and proved that surgical excision provides satisfactory control of progressive elevation of ICP and clinical deterioration in many cases ${ }^{[13]}$.Becker, et al also advocated early evacuation of traumatic contusions for the purpose of avoiding secondary complications ${ }^{[14]}$. In our study we did early evacuation of cerebral contusions usually within first 24 hours by doing Craniotomy and Evacuation, Craniotomy with Lobectomy and also craniectomy in few cases for temporal contusions. These patients had 
better outcome, decreased hospital stay and less mortality as compared to those who were managed conservatively by doing initial resuscitation, head up and oxygen inhalation, mannitol infusion and anti-epileptic drug therapies.

\section{CONCLUSION:}

It is concluded that early evacuation of cerebral contusion due to traumatic brain injury in patients with mild to moderate GCS improves neurological status of the patient, decreases mortality and hospital stay and abolishes the chance of contusion expansion.

\section{CONFLICT OF INTEREST:}

All authors disclose no conflict of interest.

\section{Grant Support \& Financial Disclosures: None.}

\section{REFERENCES:}

1. Maas AI, Stocchetti N, Bullock R (August 2008). Moderate and severe traumatic brain injury in adults: Lancet Neurology. 2008; 7 (8): 728-41.

2. Langlois J. A. Rutland-Brown W. Wald M.M. The epidemiology and impact of traumatic brain injury: a brief overview. J. Head Trauma Rehabil. 2006;21:375-378.

3. Selassie A.W. Zaloshnja E. Langlois J.A. Miller T. Jones P. Steiner C. Incidence of long-term disability following traumatic brain injury hospitalization, United States, 2003. J. Head Trauma Rehabil. 2008;23: 123-131.

4. Zaloshnja E. Miller T. Langlois J.A. Selassie A.W. Prevalence of long-term disability from traumatic brain injury in the civilian population of the United States, 2005. J. Head Trauma Rehabil. 2008;23:394-400.

5. Langlois J. A. Rutland-Brown W. Wald M.M. The epidemiology and impact of traumatic brain injury: a brief overview. J. Head Trauma Rehabil. 2006;21:375-378.
6. Alahmadi H. Vachhrajani S. Cusimano M.D. The natural history of brain contusion: an analysis of radiological and clinical progression. J. Neurosurg. 2010;112: 1139-1145.

7. Hardman JM, Manoukian A. Pathology of Head Trauma. Neuroimaging Clinics of North America. 2002; 12 (2): 175-187.

8. Rogers AJ, Maher CO, Schunk JE, Quayle K, Jacobs $E$, Lichenstein $R$, et al. Incidental findings in children with blunt head trauma evaluated with cranial CT scans. Pediatrics. Aug 2013;132(2):e356-63.

9. Bendinelli C, Bivard A, Nebauer S, Parsons MW, Balogh ZJ. Brain CT perfusion provides additional useful information in severe traumatic brain injury. Injury. Sep 2013;44(9):1208-12.

10. Anderson KE, Taber KH, Hurley RA. Functional Imaging. In: Silver JM, McAllister TW, Yudofsky SC.Textbook of Traumatic Brain Injury. American Psychiatric Publishing, Washington, DC; 2005.

11. Guerrier G, Morisse E, Barguil Y, Gervolino $\mathrm{S}$, Lhote $\mathrm{E}$. Severe traumatic brain injuries from motor vehicle-related events in New Caledonia: Epidemiology, outcome and public health consequences. Aust N Z J Public Health. 2015;39:188-91.

12. Umerani MS, Abbas A, Sharif S. Traumatic brain injuries: Experience from a tertiary care centre in Pakistan. Turk Neurosurg. 2014;24:19-24.

13. Kawamata T, Katayama Y. Surgical management of early massive edema caused by cerebral contusion in head trauma patients. Acta Neurochir Suppl. 2006; 96:3-6.

14. Becker D, Miller J, Ward J, Greenberg R, Young $H$, Sakalas R: The outcome from severe head injury with early diagnosis and intensive management. J Neurosurg 47:491-502, 1977. 
Authors' Contribution:

Zubair Ahmed khan: Over all Supervision of data collection, analysis and manuscript writing.

Habib Sultan: Study Design and final approval of manuscript.

Amir Aziz: Data collection and literature search.
Shahrukh Rizvi: Help in data collection and statistical analysis.

Tauqeer Ahmed: Help in data collection and final draft of study.

Waseem Ahmad: Help in manuscript writing.

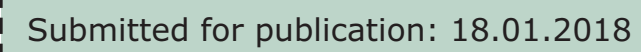

When Imam Ali was asked about Faith in Religion, he replied that the structure of faith is supported by four pillars endurance, conviction, justice and jihad. Hazrat Ali (Karmulha Wajhay) 